NBER WORKING PAPERS SERIES

TESTING THE IMPORTS-AS-MARKET-DISCIPLINE HYPOTHESIS

James Levinsohn

Working Paper No. 3657

NATIONAL BUREAU OF ECONOMIC RESEARCH

1050 Massachusetts Avenue

Cambridge, MA 02138

March 1991

This paper is part of NBER's research program in International Studies. Any opinions expressed are those of the author and not those of the National Bureau of Economic Research. 
NBER Working Paper \#3657 March 1991

TESTING THE IMPORTS-AS-MARKET-DISCIPLINE HYPOTHESIS

\section{ABSTRACT}

It has long been believed that international competition forces domestic firms to behave more competitively. I term this the imports-as-market-discipline hypothesis. I construct a simple static oligopoly model and estimate the model using panel data from Turkish manufacturing firms. The data span the course of a dramatic trade liberalization. Looking for changes in price-marginal cost markups as trade policy shifts, I test the imports-as-market discipline hypothesis. In all five industries to which the hypothesis is relevant, markups change in the direction predicted by the theory. These changes are statistically significant in all but one of the five industries.

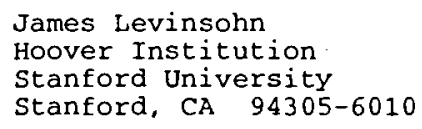




\title{
Testing the Imports-As-Market-Discipline Hypothesis
}

\author{
James Levinsohn
}

\section{Introduction}

The theory of international trade policy is becoming quite well developed. Myriad policies, real and imagined, have been investigated in models of perfect competition and, more recently, in models of imperfect competition. The more recent literature is quite nicely surveyed (and extended) in Elhanan Helpman and Paul Krugman's Trade Policy and Market Structure (1989). Econometric studies of trade policy under imperfect competition, in contrast to the theoretical investigations, are scarce. It is perhaps telling that Helpman and Krugman's survey of empirical work in the field does not mention a single econometric study.

Recent empirical work in trade policy and market structure consists primarily of calibrated simulation models. Examples include Avinash Dixit's (1988) study of the United States automobile industry, Paul Krugman and Richard Baldwin's (1988) study of the semiconductor market, Alasdair Smith and Anthony Venables' $(1988,1989)$ studies of several industries in the United Kingdom, and Dani Rodrik's (1988) study of various Turkish industries. Although none of these studies ask exactly the same question, they share some common themes. All of these are studies of trade policy under imperfect competition employing industry level simulation models. They are calibrated, not estimated, All these studies examine normative as well as positive consequences of trade policy. Also, all these studies consider the role government policy might play in altering the game firms play and are hence studies of strategic trade policies. Finally, they are all prospective. That is, they evaluate policies that could be, but are not actually, implemented.

I am grateful to Steve Berry, Jim Brander, Tim Bresnahan, Avinash Dixit, Rob Feenstra, Eban Goodstein, Gene Grossman, Jefl Mackie-Mason, A riel Pakes, Dani Rodrik, Bob Staiger, Jim Tybout, and Frank. Wolak for helpful comments and/or discussions. Also many thanks to to Lili Lui and Janet Netz for research assistance. None of the above bear any blame. I am also grateful to the World Bank which funded this paper under RPO674-46: Industrial Competition, Productive Efficiency, and their Relation to Trade Regimes. 
This paper investigates the effects of trade policy in imperfectly competitive markets, but beyond that it deviates from the above group in all the dimensions listed. Econometric estimates are employed to evaluate the positive effects of a trade policy that was implemented. In many respects, the goal of this paper is much more modest than its predecessors. The policy studied is quite simple and not especially strategic. The welfare consequences of the policy are not addressed. I test what Helpman and Krugman call "the oldest insight in this area (of trade policy and imperfect competition.) This is the idea that international trade increases competition." 'When faced with intensified international competition, domestic industries, which may have reaped oligopoly profits in a protected domestic market, are forced to behave more competitively. This phenomenon is frequently claimed to be especially relevant in developing countries where the protected domestic market often will only support a few firms. (See Rodrik (1988) for a discussion.) I term this phenomenon the imports-as-market-discipline hypothesis.

This is a hypothesis about how firms respond to a change in trade policy. As important, intuitive, and old-fashioned as the hypothesis may be, it appears that it has not been rigorously tested with firm-level data. ${ }^{2}$ There is, though, an older body of emprirical research, adopting what is sometimes called the "Structure-Performance-Conduct" paradigm that addressed the imports-as-market-discipline hypothesis. An especially entertaining review of that literature is found in Richard Caves (1985). Treating profits as directly observable and concentration ratios as valid measures of market power, that body of literature found that, "the larger is imports share of domestic sales, the smaller is the effect of the concentration of domestic producers on the profits earned by those producers." (Caves, p. 2) Most of these studies used industry-level data and ran cross-industry regressions, although some studies used time series.

In contrast to these earlier studies, I adopt the apporach of what has come to be called the new empirical industrial organization. I estimate a very simple model of the opti-

\footnotetext{
1 The idea certainly is an old one. According to Richard Caves, Jeffrey Frankel, and Ronald Jones $(1990)$, "'The tariff is the mother of the trusts' was a charge heard often in the United States at the end of the nineteenth century."
} effects of trade liberalization in the Ivory Coast. 
mizing oligopolistic firm while treating important parameters such as demand elasticities, the mode of market conduct, and marginal costs as unobservable. Because the importsas-market-discipline hypothesis is a hypothesis about firm behavior, testing it carefully requires firm-level data. This paper asks whether, in a particular instance, the theory is supported by the data.

The trade policy studied is the large scale removal of import protection in the Turkish manufacturing sector in 1984. The methodology employed is constructed to accommodate the idiosyncracies of the available data, and in this case the data consist of detailed plant level information on inputs and outputs for almost all manufacturing firms in Istanbul, Turkey from 1983 to 1986 . Because the available panel data are broadly representative of the sort of data available to researchers using manufacturing censuses, the methodology has applications beyond this particular use. The estimating equation is derived along the lines of the pioneering work of Mark Roberts (1984) and is also quite similar to estimating equations recently used by Robert Hall (1988).

The remainder of this paper is organized as follows. Section 2 gives a brief review of the dramatic trade liberalization that Turkey experienced in the early 1980's. This trade reform provides an excellent experiment for which there is relatively plentiful firmlevel data. Since the availability of data constrains the theory which generates testable hypotheses, the data are described before any theory is presented. Discussion of the data constitutes section 3 . Section 4 describes the very straightforward theoretical model which leads to a structural estimating equation. Section 5 discusses several econometric concerns, and results are presented and evaluated in section 6 . Concluding remarks are gathered in section 7 .

\section{The Experiment: Trade Liberalization in Turkey}

If an index of Turkish economic health had been listed on a major stock exchange at the close of the 1970's, the shrewd investor would have been sorely tempted to have bet the farm by selling short. In the very near term, such a hypothetical investor would have done quite well. In 1980, GNP fell 1.1 percent, inflation was up to 107 percent, and the current account deficit was 5.5 percent of GNP. Trade policy was a protectionist's dream. The 
headaches that confronted an export producing firm included an over-valued exchange rate, difficulty obtaining credit, complex rules limiting one's ability to extend credit to international customers, and administrative difficulty obtaining imported inputs. Even if import-substituting producers did not receive any protection, potential entrepreneurs presumably thought twice before embarking on an export producing venture.

Import competing producers, though, did receive tremendous protection from international competition. Like many countries that placed a heavy emphasis on importsubstitution, Turkey employed an extensive and complicated system of tariffs, taxes and non-tariff barriers. ${ }^{3}$ The average tariff in 1981 was estimated at 49 percent (Yagci (1984)). The general pattern of tariffs was one in which rates were lowest in raw materials and intermediate inputs that were not produced domestically and were highest on finished products that were produced domestically. Rates on imports from the EEC were slightly lower.

The Turkish system of quotas, import licencing, and foreign exchange regulations were (perhaps not accidentally) very complicated. All goods were, in effect, placed on one of three lists. Goods on the Liberalized List could be imported freely, but these were mostly inputs not produced domestically. A second list contained quotas on most other imported products. Importation of goods not on either list was simply prohibited (hence in effect creating the third or Prohibited List.) Calculating tariff equivalents to non-tariff barriers is a well established yet tricky business. Krueger (1974) estimated that for over half of all products imported, the tariff equivalent was over 100 percent. In any case, there is little doubt that non-tariff barriers provided domestic producers with considerable additional protection.

Beginning in 1980 , Turkey began a remarkably successful transformation from an inward looking to an outward oriented open economy. ${ }^{4}$ The first wave of this liberalization took place in 1980, and these measures were primarily directed at encouraging exports. Measures included a real devaluation of about 30 percent in 1980 alone, tax rebates to

3 A detailed discussion of protection is found in Fahrettin Yagci (1984). Much of the discussion of pre-liberalization trade policy is drawn from this. Surveys of earlier trade policy and its effects are found in Anne Krueger (1974).

4 For a more detailed discussion of this transformation see Aricanli and Rodrik (1990) (especially the chapter by Baysen and Blitzer) from which mucl of this discussion is drawn, and Rodrik (1990). 
exporters which rose from 9 to 23 percent and whose base expanded from 61 to 87 percent, credit subsidies to exporters, and foreign exchange allocations that allowed the duty-free import of many intermediate and raw materials used to produce exportables. By 1983, merchandise exports about doubled. By the end of 1983, the initial burst of export promotion had produced admirable results.

While this initial burst of liberalization was very good for Turkish economic performance, the timing is not as welcome for the purposes of this study, since the first year of available data is 1983 . If the export promotion might have been expected to increase the profits of exporting firms, most of this effect is not going to show up in a data set that does not include 1980-82. Fortunately (for this study, if not the Turkish economy), the liberalization of imports came later.

Significant import liberalization measures were announced in December, 1983. The 1984 Import Program significantly reduced both tariff and non-tariff barriers. A new more liberal system of non-tariff barriers was established. Goods which were no longer on either of three new lists could now be freely imported. Prohibitive quotas on some narrowly defined consumer goods remained and these constituted the Prohibited List. ${ }^{5}$ Another list consisted of luxury items on which a special levy was placed. The third list, called the Licence List, covered 28 percent of 1984 imports, and importation of these goods required a special licence. The Licence List was the most important form of non-tariff protection for Turkish manufacturing after liberalization, yet it was much less binding and much less comprehensive than the previous system of non-tariff barriers. Indeed, the Licence List in 1984 covered only 28 percent of imports - a more than twofold decrease.

Along with the removal and reduction of non-tariff barriers, tariffs were reduced to about 20 percent for most products. In general, industries that were hardest hit by the removal of NTB's faced the smallest tariff cuts. Table 1 presents the 3 -digit ISIC industries in which, in 1984, Turkey was a net importer and the level of 1984 imports. Non-electrical machinery (ISIC 382) and industrial chemicals (ISIC 351) are, by an order of magnitude,

\footnotetext{
5 This list was gradually eliminated and by 1985 about the only commodities still on it. were
} narcotics and weapons. 
where most imports are. ${ }^{6}$ Table 2 provides industry-specific information on the estimated changes in protection. This table is adapted from Baysen and Blitzer. In all but two industries, ISIC 384 and ISIC 385, protection fell in 1984. In these two industries, the rise in the tariff level was estimated to more than compensate for the reduction in quantitative restrictions. Only in non-ferrous metals (ISIC 372) did non-tariff barriers actually increase.

The broad and dramatic import liberalization of 1984 provides an excellent natural experiment with which to investigate the imports-as-market-discipline hypothesis. Econometric investigations, though, are typically constrained by the availability of data. In the next section, the available data are described.

\section{The Data}

The available data are from the Turkish manufacturing census and were collected by the Turkish State Institute of Statistics. The data are annual observations at the plant level and cover all plants in the greater Istanbul area from 1983 to 1986 . Because the manufacturing sector is so heavily concentrated around Istanbul, the data provide fairly comprehensive coverage of Turkish industry. Plants are identified only by an identification number and if some plants are owned by the same parent firm, this relationship is not in the data. Henceforth, the terms plant and firm will be used interchangeably. Issues of intra-firm transfer pricing of inputs and within firm cross-plant collusive pricing of outputs are not addressed due to the structure of the data.

Table 3 lists the number of firms in each industry and the 19856 -firm concentration ratios. Although all industries are comprised of many firms, the six firm concentration ratio indicates that the size distribution of firms is hardly uniform. While this ratio says nothing about firm behavior, it does provide some preliminary, albeit only suggestive, evidence that the perfect competition assumption may not be uniformly valid. A caveat is in order, though. The concentration ratios in Table 3 only indicate what proportion of domestic output is produced by the biggest six firms. Insofar as international competition

6 The only 3-digit manufacturing ISIC code not in Tables 1 and 2 for which Turkey was a net importer is ISIC 354 - petroleum products. No information about the levels or changes in protection were available. Also, much of this industry is heavily regulated or owned outright by the government. 
limits any domestic market power, a high concentration ratio may say very little about the liberalized open economy industry structure.

Available firm-level data are mostly comprised of detailed information on firm expenditures and the value of output. Since I will be concerned with price-marginal cost mark-ups, costs which do not vary with the level of output will play no role. Rather I concentrate the below discussion on inputs that do vary with output. ${ }^{7}$ On the input side, there is firm-specific information on the number of production workers and payments to production workers, hence giving firm-specific wages. Expenditures on fuel are provided, and a Turkish manufacturing energy price index is used to yield both price and quantity of fuel. Expenditures on raw materials and other purchased variable inputs are provided as is an industry-specific input price index which is used to convert these expenditures to quantities.

Data on firm-level capital stocks are not provided. ${ }^{8}$ Although levels of capital are not available, detailed firm-level information is available on capital investment. While the lack of data on capital stocks will provide some hurdles (for example, not being able to estimate a conventional production function), there are reasons to believe that in Turkey annual expenditures on capital investment may be better measured than the value of the firm's entire existing capital stock. The cost of capital is assumed to be 7 percent. ${ }^{9}$

On the output side, data are available on the value of firm output. Sales and inventory changes are individually available. Price is an industry-specific output price index. Firmspecific output prices are not available. Because only four years of data are available and prices are not firm-specific, estimation of industry demand elasticities is infeasible. This constraint is typically very important in empirical models of the firm, since demand elasticities play a key role in the oligopolistic firm's behavior.

\footnotetext{
$7 \quad$ A very detailed description of the data is provided in the Data Appendix.

8 For a small sub-sample, capital stock data are sporadically available, but this is too spotty to be of much use.

9 Setting the cost of capital to 20 percent instead of 7 percent does not change the qualitative results. This is probably because investment, as a share of output, is very small in these industries over this time period.
} 
All data were checked for obvious miscodes and these observations were discarded. Finally, the data, excluding the occasional missing observation or miscode, form a balanced panel. i.e. All firms show up in all years. The information concerning firm entry and exit inherent in an unbalanced panel is not available. This will presumably induce some sample selection biases, and these are discussed in the Results section.

In sum, the available data consist of a balanced firm-level panel spanning 1983 to 1986. Input quantities are firm-specific and quite comprehensive. The important exception to this is capital stock, as only its flow, investment, is measured. Input prices are industryspecific with the exception of wages which are firm-specific. Firm-specific output quantities are implicitly provided, but output price is industry-, not firm-, specific. Keeping in mind the constraints and opportunities this data set implies, I now turn to deriving a simple structural oligopoly model that generates an estimable test of the imports-as-market discipline hypothesis.

\section{Some Theory}

When modelling how trade policy and domestic market structure interact in a domestic homogenous good industry, there are many cases to consider. ${ }^{10}$ Trade policy may take the form of tariffs or quotas. An imperfectly competitive domestic market structure nay be either monopolistic or oligopolistic. If it is oligopolistic, the domestic firms might play either non-cooperatively or collusively. If they play non-cooperatively, what is the strategic variable? Domestic firms may produce with increasing, decreasing, or constant returns to scale. The foreign firm(s) may produce a perfect or imperfect substitute good. All these cases, and others, are summarized by Helpman and Krugman.

With so many possible theoretical permutations, it is striking that a tariff or a quota will, in almost every case, increase price-marginal cost markups. ${ }^{11}$ Furthermore, except

Throughout, I assume the domestic industry produces a homogenous good. This is consistent with only observing a domestic industry-wide output price. Trade policy and market structure with differentiated products raises yet more issues. These are summarized in Helpman (1990). While an empirical test of some of the issues that arise in the case of domestic firms producing differentiated products would be welcome, it is beyond the scope of this paper.

11 There is one case in which liberalization leads to the oligopolists taking the hit in profits by selling less, but not adjusting price, hence the use of 'almost' above. 
in the case of a repeated game framework, quotas tend to provide more protection than do tariffs. Indeed, there are at least 30 cases one could consider and every one of these scenarios has increased protection yielding no decrease in price-marginal cost markups. Conversely, liberalization, the theory predicts, will not lead to an increase in these markups. The relative unanimity of the theory's predictions is welcome from the point of view of empirical work. I will test what happened to mark-ups in several industries, and the structural oligopoly model that is appropriate for one industry is almost surely wrong for another. That the different models yield the same predictions greatly enhances the interpretability of the results.

Given the theory's strong predictions about mark-ups and trade liberalization, the next step is to derive an estimable equation that satisfies the constraints of the data and is consistent with a fairly general structural model of static oligopoly.

The output of firm $i$ in year $t$ is denoted $q_{i t}$ and is a function of a $j \times 1$ vector of variable inputs, $\mathrm{L}_{i t}$, and capital, $K_{i t}$. Firm output is given by:

$$
q_{i t}=\phi_{i 1} f\left(L_{i 1}, K_{i 1}\right)
$$

where $\phi_{i t}$ is a firm and period specific multiplicative productivity shock. Allowing the shock to vary over firms permits firm heterogeneity since for given inputs, some firms are surely more productive than others, while letting the shock vary over time captures both industry-wide shocks and other exogenous increases of output over time. (The latter is sometimes labeled technical progress and modelled additively, but this method of separately identifying productivity shocks and technical progress seems arbitrary and is hence abandoned.) The function $f$ may exhibit constant, increasing, or decreasing returns to scale.

The productivity shock is assumed to follow a random walk with firm-specific drift. The forecast error is assumed normally distributed with mean zero and variance $\sigma^{2}$. Hence,

$$
\phi_{i t}=\phi_{i, t-1}+k_{i}+\epsilon_{i t} ; \quad \epsilon_{i t} \sim N\left(0, \sigma^{2}\right) .
$$

That the productivity shock enters (1) multiplicatively captures the idea that the extra output produced in a good year, for example, is not independent of the level of inputs. 
An implication of the normally distributed forecast error is that for some very negative draws of $\epsilon_{i t}, q_{i t}$ would become negative. I assume $q_{i t}$ is bounded below at zero and for large enough negative draws of $\epsilon_{i t}$, the firm simply closes shop and goes out of business.

The unexpected part of the productivity shock, $\epsilon_{i t}$, is assumed to be comprised of two parts. Specifically,

$$
\epsilon_{i t}=\lambda_{t}+\mu_{i t}
$$

where $\mathrm{E}\left(\lambda_{t}\right)=\mathrm{E}\left(\mu_{i t}\right)=0, \mathrm{E}\left(\lambda_{t}, \lambda_{s}\right)=\sigma_{\lambda}^{2}$ if $t=s$ and analogously for $\mu$. The first component of the disturbance, $\lambda_{t}$, is the productivity shock to variable and quasi-fixed factors. Note that it is only indexed by time and not by firm. This is an important assumption, and its reasonableness depends crucially on the exact nature of the panel data set. By indexing $\lambda_{t}$ only by $t, \mathrm{I}$ am assuming that all firms within a given 3 digit industry in Istanbul, Turkey face the same productivity shock to variable factors in any given year. For example, a fuel price increase or fall in raw material prices hits all firms in the given industry. This assumption makes use of the detailed nature of the panel data set. In other panel data sets, one across industry aggregates in the U.S. over time, for example, the assumption is not plausible. $\mu_{i t}$ is that component of the productivity shock that is idiosyncratic to firm $i$ in year $t$ and is assumed orthogonal to $\lambda_{i}$. In other words, $\mu_{i t}$ does not effect the choice of variable inputs. Firm idiosyncratic phenomenon captured by $\mu_{i t}$ might include being victimized by robbery or extortion, closing the plant for the owner's daughter's wedding, and the like.

The component of the productivity shock that effects the productivity of the vector $L_{i t}$ and $K_{i t}$ will almost surely be correlated with how these factors change in response to the shock. Therefore, $\mathrm{E}\left(\lambda_{t}, L_{j i t}\right.$ or $\left.K_{m i t}\right) \neq 0$, so a component of the disturbance is no longer orthogonal to the included right-hand side variables. This will prove to be an important econometric concern and is discussed in section 5 .

The first step in deriving an estimating equation is to take a first order Taylor series approximation of $q_{i, t-1}$ around $q_{i t}$. This yields:

$$
\Delta q_{i t}=\phi_{i t}\left[\sum_{j} \frac{\Delta f_{i t}}{\Delta L_{j i t}} \Delta L_{j i t}+\frac{\Delta f_{i t}}{\Delta K_{i t}} \Delta K_{i t}\right]+f_{i t} \Delta \phi_{i t}
$$


where $\Delta$ is the first difference operator defined by $\Delta x_{i t}=x_{i t}-x_{i, t-1}$. It should be noted that a first order Taylor series approximation may be quite satisfactory if returns to scale are more or less constant, but if returns to scale are dramatically increasing or decreasing, the approximation is not precise. ${ }^{12}$ There is nothing behavioral about (4); it is just arithmetic. I turn now to the oligopolistic firm's profit maximization problem.

The timing of when managers learn the productivity shock is important. I assume managers observe period $t$ 's productivity shock prior to setting inputs. ${ }^{33}$ Firm profits, $\pi_{i t}$, are given by:

$$
\pi_{i t}=p_{t} q_{i t}-\sum_{j=1}^{J} w_{i j t} L_{j i t}-r_{m t} K_{m i t},
$$

where $p_{t}$ is the price of the homogenous good in period $t, w_{i j t}$ is the price of factor $L_{j i t}$, and $r_{m t}$ is the cost of capital.

The manager must choose the optimal mix of inputs and the optimal quantity of output. Using discrete derivatives, profit maximization with respect to input $L_{j i t}$ implies:

$$
\begin{aligned}
\phi_{i t} \frac{\Delta f_{i t}}{\Delta L_{j i t}}=\left[1+\frac{s_{i t} \theta_{i t}}{\eta_{t}}\right]^{-1} \frac{w_{i j t}}{p_{t}}, \text { where } \\
s_{i t}=\frac{q_{i t}}{Q_{t}}: \text { Market Share, } \\
\eta_{t}=\frac{\Delta Q_{t}}{\Delta p_{t}} \frac{p_{t}}{Q_{t}} \quad: \text { Arc Elasticity of Demand, and } \\
\theta_{i t}=\frac{\Delta Q_{t}}{\Delta q_{i t}} \quad ; \text { Conjectural Variations Parameter. }
\end{aligned}
$$

An analogous condition holds for capital. Equation (6) makes use of the assumption that firms take input prices as given. As parameterized, $\theta_{i t}$ is set to one if firms play Nash in

\footnotetext{
12 Experiments estimating production functions without a capital input variable, since it is not available, suggest that the constant returns to scale assumption is empirically quite reasonable for the industries under study. (1988) as well as in the empirical industrial organization literature (see Bresnahan (1989). The alternative assumption implies that managers maximize expected profits and in an oligopolistic set-up, this will involve higher moments of the distribution of outcomes. This complicates estimation.
} 
quantities and zero if they play Nash in prices. ${ }^{14}$

Profit maximization with respect to output levels implies:

$$
\left[1+\frac{s_{i t} \theta_{i t}}{\eta_{t}}\right]^{-1}=\frac{p_{t}}{M C_{i t}} \equiv \beta_{i t}
$$

$\beta$ will be treated as unobservable and will be estimated. It is especially convenient that the market share, demand elasticity, and mode of market conduct are all gathered together in (7), for they are each unobserved. ${ }^{15}$ On the other hand, these unobservables will not be separately identified when $\beta$ is estimated. Substituting (2), (3), (6), and (7) into (4) gives:

$$
\Delta q_{i t}=\beta_{i t}\left[\sum_{j} \frac{w_{i j t}}{p_{t}} \Delta L_{j i t}+\frac{r_{i t}}{p_{t}} \Delta K_{i t}\right]+f_{i t}\left(\lambda_{t}+\mu_{i t}\right)
$$

Note that if $(8)$ is divided by $q_{i t}$, the terms within the brackets are multiplied and divided by $L_{j i t}$ and $K_{i t}$ respectively, and we use the approximation that $\frac{\Delta X}{X}=\Delta \ln X$, one has an estimating equation along the lines of Hall (1988) and the many papers his work has inspired. Advantages of (8) over the "Hall" approach, for the problem at hand, include not requiring (unavailable) capital stock data, the absence of $q_{i t}$ from the right hand side of the equation (and the simultaneity bias that would entail), and requiring one less approximation.

The imports-as-market-discipline hypothesis focuses on how $\beta_{i t}$, the price-marginal cost ratio changes with the imposition of trade liberalization. The myriad models investigating trade policy and domestic market power in a homogenous product domestic industry predict that in imperfectly competitive industries, this ratio falls with trade liberalization. Since the shift in trade policy that gave rise to import liberalization occurred in $1984,(8)$ is rewritten as:

\footnotetext{
14 For a nice discussion of why this sort of parameterization is as theoretically misguided as it is empirically useful, see Helpman and Krugman, chapter 8.
}

15 Market share is unobserved since while I have data on most firms, I do not have data on every firm. Also, total imports by industry code are not available for every year of the sample. 


$$
\begin{aligned}
& \Delta q_{i t}=\beta_{84, i t}\left[\sum_{j} \frac{w_{i j t}}{p_{t}} \Delta L_{j i t}+\frac{r_{i t}}{p_{t}} \Delta K_{i t}\right]+ \\
& \beta_{8586, i t}\left[\sum_{j} \frac{w_{i j t}}{p_{t}} \Delta L_{j i t}+\frac{r_{i t}}{p_{t}} \Delta K_{i t}\right]+f_{i t}\left(\lambda_{t}+\mu_{i t}\right),
\end{aligned}
$$

where the independent variables are interacted with the appropriate period dummies. $\beta_{84, i t}$ is the price marginal cost ratio prior to the liberalization, while $\beta_{\mathbf{8 5 8 6 , i t}}$ is the markup after liberalization. Equation (9) is basis for the estimating equation, and the importsas-market-discipline hypothesis can be stated as $\beta_{84, i t}>\beta_{8586, i t}$. In the next section, estimation of the $\beta_{i}$ 's is discussed.

\section{Econometric Concerns}

The estimating equation, (9), is linear in the price-marginal cost ratio, $\beta_{i t}$. It is nonlinear in changes in input levels, input prices, and output price, but these are all data. Ordinary least squares (OLS), though, would be inappropriate. Four very straightforward econometric concerns merit brief discussion. The first pertains to the probable correlation between the period-specific random effect, $\lambda_{t}$, and the included independent variables.

The economics of the situation strongly suggest that productivity shocks to variable factors, which are observed by managers prior to setting levels of inputs, will not be independent of changes in outputs. That is, in a good year, a large positive $\lambda_{t}$ will lead managers to use more of an input. Hence, $E\left(\lambda_{1}, \Delta L_{j i t}\right.$ or $\left.\Delta K_{m i t}\right) \neq 0$. OLS in the presence of this non-independence gives biased estimates. Abbott, Griliches, and Hausman (1989) have shown that in this particular situation, OLS estimates are upwardly biased. The ideal solution would be to find firm-level instruments that cause changes in inputs but are uncorrelated with the productivity shock. This is a tall order to fill. Likely and available candidates for instruments are lagged values of $\Delta L_{j i t}$ and $\Delta K_{m i t}$ and firm-specific wages. (Other input prices, while assumed exogenous, do not vary across firms.) These potential instruments present serious problems. First, since the estimating equation is already in first-differences and the panel consists of only 4 years, using lagged variables as instruments decreases the degrees of freedom by a third. More importantly, the pre-liberalization markups would not be estimable. Second, if productivity shocks are random (net of the drift 
term $k_{i}$ ) as posited, there is no economic reason to believe that first-differences in inputs should be serially correlated. Hence, even in the absence of the degrees of freedom issue, the fit of these instrument is likely to be quite poor. ${ }^{16}$

Hausman and Taylor (1981) have shown that when the random effect is correlated with the included independent variables, modelling the random effect as a fixed effect yields consistent and unbiased, albeit inefficient parameter estimates. Given the lack of appropriate instruments, this approach is adopted, and $\lambda_{t}$ is modelled as a time period fixed effect. Since the estimated variance-covariance matrix of parameter estimates will not achieve its minimum bound, hypothesis tests will be too strong. For the problem at hand, hypothesis tests will address whether $\beta_{i t}$ changes over time and whether levels of $\beta_{i t}$ are significantly different from one. The inefficiency of my estimates will, for given data, make it harder to accept that $\beta_{i t}$ 's are significantly different from year to year and easier to accept that they are equal to one.

A second econometric issue arises due to the presence of price, $p_{t}$, as a non-linear component of the independent variable. Since the markets under investigation are potentially oligopolistic, any one firm might affect the industry-wide price. If, for example, $\mu_{i t}$ was positive, output would be higher, and this might lead to a lower price for all firms. Like the previously discussed econometric issue, an instrumental variables approach will solve the problem. Unlike with the first econometric issue, instruments are plentiful because price is only indexed by time. Firm-level instruments are not required. Letting $X$ denote the independent variable in (8), where,

$$
X_{i t}=\frac{1}{p_{t}}\left(\sum_{j=1}^{J} w_{i j t} \Delta L_{j i t}+r_{m t} \Delta K_{m i t}\right),
$$

note that $p_{t}$ is the only endogenous variable entering $X_{i t}$. Wages and capital costs are taken as exogenous by any single firm, and changes in inputs are, after the inclusion of $\lambda_{t}$, orthogonal to the disturbance. Therefore the term $\left(\sum_{j=1}^{J} w_{i j t} \Delta L_{j i t}+r_{m t} \Delta K_{m i t}\right)$ is

16 The difficulty in finding appropriate instruments at the firm level is demonstrated by Harrison who finds that instrumental variables (IV) estimates of $\beta$ are greater than OLS estimates when, if instruments were appropriate, the IV estimates should be smaller. The same difficulty is evidenced in Hall who uses industry aggregated data. This is discussed in Abbott, Griliclies, and Hausman. 
itself exogenous. This term is included as an instrument for $X_{i t}$. The instrument for $p_{t}$ should be corselated with price and independent of industry-specific productivity shocks. The economy-wide wholesale price index for Turkey is used to instrument for $p_{t}$.

A third econometric issue concerns the disturbance term, $f_{i t}\left(\lambda_{t}+\mu_{i t}\right)$. Due to the presence of the $f_{i t}$ term, the disturbance is likely to be heteroskedastic. $f_{i t}$ is the output of firm $i$ in year $t$ in the absence of any productivity shock. As such, it is unobservable, but it is reasonable to suppose that the composite disturbance term will be lasger for bigger firms. While the White correction will give a consistent estimate of the variancecovariance matrix, it will not necessarily be efficient. Since theory dictates the form of the heteroskedasticity, weighted least squares is employed. It is assumed that the variance of the disturbance is proportional to labor expenditures. While this is not going to be an exact correction, it will capture the idea that the disturbance has greater variance for larger firms. ${ }^{17}$

The final econometric issue concerns the imposition of prior identifying restrictions on $\beta_{i t}$. As written in ( 8 ), the price-marginal cost ratio is indexed by both firm and period. This implies negative degrees of freedom and is of course econometrically infeasible. Some prior restrictions are necessary. This issue does not arise, by assumption, in the theoretical models of trade policy and oligopoly. There, a symmetric domestic market structure with $n$ identical firms is the standard assumption. In that case, all domestic firms have, by construction, identical mark-ups. In the real world, though, the size distribution of firms is not uniform.

One oft-used approach is to assume that all firms have the same mark-up. ${ }^{18} \mathrm{~A}$ possible drawback to this approach is its theoretical implication that, as seen in (7), larger firms (bigger $s_{i t}$ ) act more competitively (smaller $\theta_{i t}$ ). The advantage of this approach is that despite its theoretical inelegance, it frequently fits the data much better than the

\footnotetext{
17 Another implementation of weighted least squares frequently used in a panel context is to empirically correct for the heteroskedasticity by dividing through by the firm-specific variance of the disturbance, $\sigma_{i}$. This correction is not used here because it is hard to believe that three observations will yield a precise estimate of $\sigma_{i}$.
}

18 This is the approach implicitly adopted by Abbott, Hausman, and Griliches, Harrison, Hall (in a macroeconomic context), and the many researchers who estimate cost functions with data from more than one firm. 
usual alternative. That alternative is to assume ex ante that firms play Cournot. This implies, plausibly enough, that firms with larger market shares have lower costs and higher markups. This approach sits well with the theory and, in this case, quite poorly with the data. A middle-of-the-road approach is to let markups vary non-linearly with firm size and not impose the relation between firm size and mark-ups except to require that larger markups are associated with larger market shares. I experimented with both this approach and the approach imposing Cournot behavior and consistently obtained nonsensical results and a very poor fit. Entire industries were pricing at a fraction of marginal cost. Finally, I experimented with estimating markups for the six largest firms separate from the other firms and seeing if patterns emerged. None did, and, again, the data seem to imply markips unrelated to firm size. Hence, I assume markups are constant across firms in a given period so $\beta_{i t}=\beta_{t}$.

\section{Results and Interpretation}

Equation (9) was estimated separately for each industry using the firm-level panel data described in section 3 . The results are summarized in Table 4 . There we see that estimated markups are in general quite precisely estimated. Almost all of the 22 markups are quite precisely estimated as the standard errors are in general small relative to the estimates. This is especially striking since the estimated standard errors are inflated due to the treatment of the random effect as a fixed effect. The precision of the estimates is especially useful, for it makes tests of changes in markups, discussed below, much more powerful.

There are two economic, as opposed to econometric, reasons to believe that the estimated markups in Table 4 are not the true markups in Turkish manufacturing from 1983-86. First, the industry panels are balanced and do not contain information on firms that may have entered or, more importantly, exited during the period spanning the data. If firm level data on these firms were available, the selectivity bias could be corrected. In the absence of this data, we can sign the bias. If we make the very plausible assumption that it was the less efficient firms that exited $(P<<M C)$, then excluding these firms from the sample gives rise to estimated markups higher than the true markups. 
On the other hand, there is an important reason to believe that the estimated markups are lower than the true markups. Firms, when confronted with a manufacturing census form, may understate their profitability. Turkish firms may not, perhaps with good reason, trust the wall of confidentiality that separates the census bureau from the internal revenue service in most developed countries. To the extent that this is the case, firms will tend to understate revenues and/or overstate costs. The relative importance of these two possibly offsetting biases is unknown.

With these possible biases in mind, we turn to discussion of the magnitudes of the markups. An economically insightful way to interpret the markups is to ask whether prices equalled, exceeded, or were less than marginal costs. The null hypothesis is that prices equalled marginal costs $(\beta=1.0)$ and an f-test tests this hypothesis. The results of these tests are presented in Table 5.

Prior to the change in trade policy, six industries were pricing at marginal cost, three above marginal cost, and two below marginal cost. Of the three industries pricing above marginal cost, markups are moderate for two (ISICs 352 and 383) where they are 1.32 and 1.50 respectively. Prior to liberalization, the estimated markup in ISIC 361 , the manufacture of pottery, earthenware, and china, is 5.39. This is quite large. This is an industry, though, in which marginal costs are probably quite low. In many plants, machines produce the output using inputs such as sand and clay which are themselves very inexpensive. This is also the industry in which markups are least precisely estimated.

In the steel and iron (ISIC 371) and non-electrical machinery (ISIC 382) industries, estimated marginal costs exceed prices prior to the liberalization. Were the estimated ratios a long-run equilibrium instead of just a snapshot in time, the estimates would not be plausible. As estimated one-period behavior, though, they are more plausible. In the presence of significant start-up costs, firms may well decide to endure a loss if they believe it to be temporary. This may be the case in the machinery industry where the estimated price-marginal cost ratio is .848 . This ratio, while low, is credible. The very low preliberalization price-marginal cost ratio of .620 for the steel industry is probably explained by the fact that this industry, more than any other industry in Turkish manufacturing, is government controlled. In 1981, the most recent year for which data is readily available, 
$58.7 \%$ of the value added in this industry was produced by government owned plants. ${ }^{19}$ The profit maximizing framework employed in section 4 may be especially inappropriate for this particular industry.

After the trade liberalization, another industry (ISIC 372) has an estimated pricemarginal cost ratio less than one. This is not inconsistent with the notion that in the presence of adjustment costs and sunk costs, a firm may lose money while it adapts to the new trading environment. It should be noted, though, that while this explanation probably has some real world relevance, it is an explanation that lies outside of the framework of the simple oligopoly model that generated the estimating equation.

Tables 4 and 5 addressed the issue of marginal cost pricing in import-competing Turkish manufacturing. Those tables do not, though, directly address the imports-as-marketdiscipline hypothesis. Recall that the hypothesis states that in imperfectly competitive, import-competing industries, trade liberalization gives rise to lower price-marginal cost ratios. Conversely, in industries in which protection increased, price-marginal cost ratios should either increase if the protection affords domestic firms market power or stay the same (at $P=M C$ ) if there is sufficient domestic competition. Are these simple and theoretically robust insights supported by the data? Table 6 addresses this question.

Table 6 summarizes what happened to the level of protection in the 1984 import policy shift and what happened to price-marginal cost ratios when the policy shifted. It is helpful to divide the industries into three groups. The first group is comprised of imperfectly competitive industries in which trade was liberalized (protection decreased.) Using the results in Table 5 to determine which industries are imperfectly competitive prior to liberalization, we see this first group consists of three industries-ISICs 352, 361, and 383. The second group is comprised of the two industries (ISICs 384 and 385) that experienced an increase in the level of protection. The third group is comprised of industries which priced at or below marginal cost and experienced trade liberalization. The imports-as-market-discipline hypothesis concerns only the first two groups. It does not pertain to industries which are, prior to liberalization, already perfectly competitive. In those industries, there is nothing for imports to discipline. I discuss each group in turn.

19 See Yagci for details. 
The imports-as-market-discipline hypothesis contends that firms in the first group of industries, those that were imperfectly competitive prior to liberalization, should experience a decline in markups with the onset of the liberalization. In Table 6, we see that all three industries in this group did indeed experience such a decline. In two of the three industries, the decline was statistically significant at the $90 \%$ level. The hypothesis contends that firms in the second group of industries, those that experienced an increase in protection, should see price-marginal cost ratios either increase or remain at 1.0. The hypothesis is accepted for both industries in the second group. In ISIC 384, markups increased significantly, while in ISIC 385, they also increased, but not significantly and we cannot reject marginal cost pricing post-protection. I conclude that for the Turkish case, the imports-as-market-discipline hypothesis does indeed find support in the data. All five of the industries to which the hypotliesis is relevant experienced changes in markups consistent with the theory. In only one of the five, ISIC 352, was the change not statistically significant. ${ }^{20}$

Although the imports-as-market-discipline hypothesis does not make predictions about the third group of industries, those that priced at marginal cost prior to liberalization, the results are nonetheless worth noting. The theory of commercial policy with perfect competition suggests that, in the absence of adjustment costs, firms will continue to price at marginal cost after a trade liberalization and the rents to fixed factors decline. In Table 6, we see that in three of the perfectly competitive industries, ISICs 351, 371, and 372 , there was no significant change in price-marginal cost ratios. In ISIC 382 , the ratio declined, while in ISICs 341 and 381 they increased.

\section{Summary}

That international competition might act to curtail domestic market power is an old, theoretically robust, and very simple insight. It is also a very important one. It is a part of any discussion of the welfare effects of trade policy with imperfect competition. It is also an

20 Issues of statistical significance do not apply to ISIC 385 where a result of no significant change is theoretically consistent. In that industry, I conclude domestic competition alone was sufficient to prevent oligopolistic behavior after the imposition of protection. 
oft-used argument in antitrust investigations. Since the insight is really about firms, there is an argument to be made for confronting the theory with firm-level data. The 1984 Import Program implemented by Turkey provides an excellent natural experiment with which to test the theory. The firm-level Turkish manufacturing census, which was collected annually (as opposed to every five years in many other countries) provides the appropriate data. Using a methodology tailored to the constraints of the data set, the imports-as-marketdiscipline hypothesis was tested. In all five industries that were relevant, the hypothesis was supported by the data.

The theoretical insights that were tested in this paper are very straightforward. There remains a burgeoning theoretical literature on trade policy and market structure that has yet to be econometrically tested. The relative success of this first step will hopefully motivate testing of more elaborate theoretical findings. 
Abbott, T.A., Z. Griliches, and J.A. Hausman (Undated) "Short Run Movements in Productivity: Market Power versus Capacity Utilization," Mimeo.

Aricanli, Tosun and Dani Rodrik (1990) The Political Economy of Turkey. Hampshire: MacMillan Press.

Baldwin, Richard, and Paul Krugman (1988) "Market Access and International Competition: A Simulation Study of $16 \mathrm{~K}$ Random Access Memories," in Empirical Methods for International Trade, ed. R. Feenstra. Cambridge: MIT Press.

Baysen, Tercan and Charles Blitzer (1990) "Turkey's Trade Liberalization in the 1980's and Prospects for its Sustainablity," in The Political Economy of Turkey, ed. Aricanli and Rodrik. Hampshire: MacMillan Press.

Bresnahan, Tim (1989) "Empirical Studies of Industries with Market Power," in Handbook of Industrial Organization, ed. R. Schmalensee and R. Willig. Amsterdam: North Holland.

Caves, Richard (1985) "International Trade and Industrial Organization: Problems, Solved and Unsolved," Harvard Institute of Economic Research Discussion Paper No. 1131.

Caves, Richard, Jeffrey Frankel, and Ronald Jones (1990) World Trade and Payments: An Introduction. Fifth Edition. Glenview, IL: Soctt, Foresman.

Dixit, Avinash (1988) "Optimal Trade and Industrial Policies for the U.S. Automobile Industry," in Empirical Methods for International Trade, ed. R. Feenstra. Cambridge: MIT Press.

Hall, R. (1988) "The Relation Between Price and Marginal Cost in U.S. Industry," Journal of Political Economy, 96, 921-947.

Harrison, Ann (1989) "Productivity, Imperfect Competition and Trade Liberalization in the Cote D'Ivoire," Mimeo of incomplete draft.

Hausman, J.A. and W.E. Taylor (1981) "Panel Data and Unobservable Individual Effects," Econometrica, 49, 1377-98.

Helpman, Elhanan and Paul Kŕrugman (1989) Trade Policy and Market Structure. Cambridge: MIT Press.

Helpman, Elhanan ( 1990) "Monopolistic Competition in Trade Theory," International Finance Section, Department of Economics, Princeton University, Special Papers in International Economics, No. 16.

Krueger, Anne (1974) Foreign Trade Regimes and Economic Development: Turkey. New York: Columbia University Press.

Roberts, Mark (1984) "Testing Oligopolistic Behavior," International Journal of Industrial Organization, 2, 367-383. 
Rodrik, Dani (1988) "Imperfect Competition, Scale Economies, and Trade Policy in Developing Countries," in Trade Policy Issues and Empirical Analysis, ed. Robert E. Baldwin. Chicago: University of Chicago Press.

(1990) "Premature Liberalization, Incomplete Stabilization: The Ozal Decade in Turkey," Mimeo, JFK School of Government, Harvard University.

Smith, Alasdair and Anthony Venables (1989) "Trade and Industrial Policy: Some sinulations for EEC manufacturing," Forthcoming in Empirical Studies of Strategic Trade Policy edited by P. Krugman and A. Smith.

Smith, Alasdair and Anthony Venables (1988) "Completing the Internal Market in the European Community: Some industry simulations," Forthcoming in European Economic Review.

Yagci, Fahrettin (1984) "Protection and Incentives in Turkish Manufacturing," World Bank Staff Working Paper No. 660. 


\section{Data Appendix}

Data are from the Turkish State Institute of Statistics 1983-1986 manufacturing census of Istanbul tapes.

The variable inputs that comprise the elements of $L_{i t}$, as discussed in the text, are labor, raw materials and other purchased inputs, and fuel. Exact variable definitions for these quantities and their prices are as follows.

Labor: I sum the following: Male and female high level technical personnel, Male and female medium level technical personnel, male and female foremen, and male and female workers. The wage variable is constructed by dividing annual daily wages and overtime by the above sum.

Raw materials and other purchased inputs: Expenditures on raw materials, primary inputs, packaging, and other purchased variable inputs are summed. This sum is divided by a three digit industry-specific material input price to obtain the quantity variable.

Fuel: Total fuel costs are divided by the manufacturing energy price index.

The variable $K_{i t}$ is constructed by summing the following variables: Newly purchased or imported machinery, newly purchased or imported transportation vehicles, newly purchased or imported buildings, payment in the survey year made to the one who constructs buildings for the firm, expenditures made to another party to improve and upgrade the capacity of fixed capital of the firm, newly produced machinery, transportation, and buildings by the firm itself, the firm's own expenditures to improve and upgrade the capacity of the fixed capital, second had purchases of machinery, transportation vehicles, buildings, and land, expenditures for installing fixed capital, project research expenditures for fixed capital, office equipment, and depreciation of machinery transportation and buildings. From this, I subtract any sales of fixed capital.

That concludes the description of the input variables used in estimation. The output variable is constructed as follows. Output is given by the Gross Value of Output variable on the tape. This variable is total sales revenues adjusted for changes in the inventories of semi- and finished products. These amounts are then divided by the three digit output price to give quantities.

Exact variable codes are available on request. All estimation was done using version 3.10 of RATS 386 on a Zenith 386 desktop computer with 8 megabytes of RAM. 


\begin{tabular}{|c|c|c|}
\hline \multicolumn{3}{|c|}{$\begin{array}{c}\text { TABLE } 1 \\
\text { Importing Turkish Industries in } 1984\end{array}$} \\
\hline ISIC & Category Title & $\begin{array}{r}1984 \text { Trade Balance } \\
\text { in US\$1000 }\end{array}$ \\
\hline 341 & Manufacture of Paper and Paper Products & $-63,497$ \\
\hline 351 & Manufacture of Industrial Chemicals & $-1,333,890$ \\
\hline 352 & Manufacture of Other Chemical Products & $-95,237$ \\
\hline 361 & Manufacture of Pottery, China, Earthenware & $-1,065$ \\
\hline 371 & Iron and Steel Basic Industries & $-135,143$ \\
\hline 372 & Non-ferrous metal Basic Industries & $-141,452$ \\
\hline 381 & Manufacture of Metal Products Except Machinery & $-102,659$ \\
\hline 382 & Manufacture of Machinery Except Electrical & $-1,279,370$ \\
\hline 383 & Manufacture of Electrical Machinery & $-486,604$ \\
\hline 384 & Manufacture of Transport Equipment & $-450,444$ \\
\hline 385 & Manufacture of Scientific Equipment, etc. & $-120,300$ \\
\hline
\end{tabular}

Source: CECTP, The World Bank. 


\begin{tabular}{|l|rrr|}
\hline \multicolumn{5}{|c|}{ TABLE 2 } \\
Changes in Import Protection in 1984 & \\
\hline ISIC & $\begin{array}{r}\text { Estimated Percentage of } \\
\text { Quantitative Restrictions } \\
\text { Eliminated }\end{array}$ & $\begin{array}{r}\text { Estimated Overall } \\
\text { Tariff Change }\end{array}$ & $\begin{array}{r}\text { Estimated Change } \\
\text { in Protection }\end{array}$ \\
\hline 341 & 78.5 & & Decrease \\
\hline 351 & 81.8 & -18.9 & Decrease \\
\hline 352 & 81.8 & -3.8 & Decrease \\
\hline 361 & 19.6 & -3.8 & Decrease \\
\hline 371 & 0.1 & -2.6 & Decrease \\
\hline 372 & -2.2 & 3.2 & Decrease \\
\hline 381 & 6.5 & -27.4 & Decrease \\
\hline 382 & 11.9 & -2.7 & Decrease \\
\hline 383 & 60.2 & -0.1 & Decrease \\
\hline 384 & 14.3 & -14.9 & Increase \\
\hline 385 & 100.0 & 3.8 & Increase \\
\hline & & 20.5 & \\
\hline
\end{tabular}

Source: Adapted from Baysen and Blitzer in Aricanli and Rodrik (1990). 


\begin{tabular}{|c|c|c|}
\hline \multicolumn{3}{|c|}{$\begin{array}{c}\text { TABLE } 3 \\
\text { Industry Structure }\end{array}$} \\
\hline ISIC & Number of Firms & 6-Firm Concentration Ratio \\
\hline 341 & 32 & .703 \\
\hline 351 & 36 & .836 \\
\hline 352 & 102 & .457 \\
\hline 361 & 14 & .932 \\
\hline 371 & 66 & .590 \\
\hline 372 & 34 & .784 \\
\hline 381 & 171 & .361 \\
\hline 382 & 121 & .738 \\
\hline 383 & 138 & .505 \\
\hline 384 & 79 & .807 \\
\hline 385 & 18 & .727 \\
\hline
\end{tabular}




\begin{tabular}{|c|c|c|c|}
\hline \multicolumn{4}{|c|}{$\begin{array}{c}\text { TABLE } 4 \\
\text { Estimated Price-Marginal Cost Ratios }\end{array}$} \\
\hline ISIC & $\bar{\beta}_{84}$ & $\beta_{85,86}$ & $R^{2}$ \\
\hline 341 & $\begin{array}{c}.625^{*} \\
(.268) \\
\end{array}$ & $\begin{array}{l}2.17^{*} \\
(.143) \\
\end{array}$ & .77 \\
\hline 351 & $\begin{array}{l}1.05^{*} \\
(.103)\end{array}$ & $\begin{array}{l}1.05^{*} \\
(.084)\end{array}$ & .75 \\
\hline 352 & $\begin{array}{l}1.32^{*} \\
(.087)\end{array}$ & $\begin{array}{l}1.25^{*} \\
(.078) \\
\end{array}$ & .64 \\
\hline 361 & $\begin{array}{l}5.39^{*} \\
(.829) \\
\end{array}$ & $\begin{array}{c}1.06 \\
(.673)\end{array}$ & .63 \\
\hline 371 & $\begin{array}{l}.620^{*} \\
(.151) \\
\end{array}$ & $\begin{array}{l}.746^{*} \\
(.113) \\
\end{array}$ & .26 \\
\hline 372 & $\begin{array}{l}.754^{*} \\
(.211) \\
\end{array}$ & $\begin{array}{l}.455^{*} \\
(.201) \\
\end{array}$ & .22 \\
\hline 381 & $\begin{array}{l}.822^{*} \\
(.128) \\
\end{array}$ & $\begin{array}{l}1.27^{*} \\
(.048)\end{array}$ & .63 \\
\hline 382 & $\begin{array}{l}.848^{*} \\
(.069)\end{array}$ & $\begin{array}{l}.427^{*} \\
(.092) \\
\end{array}$ & .36 \\
\hline 383 & $\begin{array}{l}1.50^{*} \\
(.189)\end{array}$ & $\begin{array}{l}1.14^{*} \\
(.126) \\
\end{array}$ & .28 \\
\hline 384 & $\begin{array}{l}.717^{*} \\
(.147) \\
\end{array}$ & $\begin{array}{l}1.35^{*} \\
(.069) \\
\end{array}$ & .67 \\
\hline 385 & $\begin{array}{l}.782^{*} \\
(.270)\end{array}$ & $\begin{array}{l}1.15^{*} \\
(.238)\end{array}$ & .48 \\
\hline
\end{tabular}

Notes: The standard errors are reported in parentheses. An asterisk indicates significance at the $95 \%$ level. 


\begin{tabular}{|c|c|c|}
\hline \multicolumn{3}{|c|}{$\begin{array}{c}\text { TABLE } 5 \\
\text { Are Prices Equal to Marginal Costs? } \\
H_{0}: \beta=1.00\end{array}$} \\
\hline ISIC & 1984 & $1985-86$ \\
\hline 341 & $P=M C$ & $P>M C$ \\
\hline 351 & $P=M C$ & $P=M C$ \\
\hline 352 & $P>M C$ & $P>M C$ \\
\hline 361 & $P>M C$ & $P=M C$ \\
\hline 371 & $P<M C$ & $P<M C$ \\
\hline 372 & $P=M C$ & $P<M C$ \\
\hline 381 & $P=M C$ & $P>M C$ \\
\hline 382 & $P<M C$ & $P<M C$ \\
\hline 383 & $P>M C$ & $P=M C$ \\
\hline 384 & $P=M C$ & $P>M C$ \\
\hline 385 & $P=M C$ & $P=M C$ \\
\hline
\end{tabular}

Notes: These test results are based on accepting or rejecting the null hypothesis at the 95 percent significance level. 


\begin{tabular}{|c|c|c|c|}
\hline \multicolumn{4}{|c|}{$\begin{array}{c}\text { TABLE } 6 \\
\text { Changes in Protection and Mark-ups }\end{array}$} \\
\hline ISIC & Protection & Mark-ups & F-test Sig. Level \\
\hline \multicolumn{4}{|c|}{ Imperfectly competitive industries in which trade was liberalized. } \\
\hline 352 & Decreased & Decreased & .54 \\
\hline 361 & Decreased & Decreased & .00 \\
\hline 383 & Decreased & Decreased & .10 \\
\hline \multicolumn{4}{|c|}{ Industries in which protection increased. } \\
\hline 384 & Increased & Increased & .00 \\
\hline 385 & Increased & Increased & .31 \\
\hline \multicolumn{4}{|c|}{ Perfectly competitive industries in which trade was liberalized. } \\
\hline 341 & Decreased & Increased & .00 \\
\hline 351 & Decreased & No Change & .98 \\
\hline 371 & Decreased & Increased & .50 \\
\hline 372 & Decreased & Decreased & .31 \\
\hline 381 & Decreased & Increased & .00 \\
\hline 382 & Decreased & Decreased & .00 \\
\hline
\end{tabular}

Notes: The significance of the f-test is such that an entry of .01 , for example, would indicate rejecting that the pre- and post-liberalization markups are equal at the $99 \%$ level. Hence, entries of $.00-.10$ in the last column indicate that the shift in markups is significant at the $90 \%$ level or higher. 